\title{
Oyunu Değiștirmek: Neden Daha Fazla Kadın Spora Katılım Sağlayamıyor?
}

\section{Changing the Game: Why Can't More Women Participate in Sports?}

Onur Burak Çelik, a, ${ }^{\text {a }}$ Meltem İnce Yenilmez ${ }^{\text {b }}$

${ }^{a}$ Dr., 299 Colt Hwy, Farmington, CT, USA.

ORCID: 0000-0003-3400-5929

b Doç. Dr., Yaşar Üniversitesi, İşletme Fakültesi, Ekonomi Bölümü Izmir/Turkey. ORCID: 0000-0002-4689-3196

\section{MAKALE BILGIISİ}

Makale Geçmişi:

Başvuru tarihi: 31 Mayıs 2019

Düzeltme tarihi: 10 Eylül 2019

Kabul tarihi: 01 Novbember 2019

\section{Anahtar Kelimeler:}

Spora Katılım

Kadın Sporcular

Spora Katılımdaki Engeller

Cinsiyet Eşitliği
ÖZ

Toplumun diğer yönlerinde olduğu gibi, kadınların da spordaki mevcut durumu uzun ve zorlu bir tarihin sonucudur. Akademik çalışmalarda, kadınların ve kız çocuklarının spora katılımı ve eğitim başarısı arasında güçlü bir bağlantı kurulmaktadır. Spor, ayrıca, cinsiyet ayrımcılığı olmadan katılımcıların fiziksel, zihinsel, duygusal, sosyal ve psikolojik gelişiminde önemli rol oynamaktadır. Elbette erkek ve kadın eşittir, ancak yine de kadınlar hala birçok az gelişmiş ve gelişmekte olan ülkelerde cinsiyet eşitsizliği sorunuyla karşı karşıyadır. Cinsiyet; sosyal sınıf, ırk ve yaş ile birlikte sporun teorik olarak tüm analizlerine dâhil edilmesi gereken önemli bir sosyal etmendir. Kadınların spor ve fiziksel aktivite alanındaki görünürlügünü ve katılımlarını artırmak toplumsal cinsiyet çalışmaları açısından da önemlidir. Bu çerçevede, bu çalışmanın amacı sporu cinsiyet analizi çerçevesinde inceleyerek bazı eksik konuları aydınlatmaktır. Ayrıca, cinsiyetçi yaklaşımı ortadan kaldırmak için kadınların karar verme ve liderlik pozisyonlarında yer almalarını sağlamak, sporda şiddet, istismar ve tacize karşı savaşmak için politikaların geliştirilmesi ve uygulamaya başlaması gerekliliği belirtilmektedir.

\section{A B S T R AC T}

As in other aspects of society, the current status of women in sports is the result of a long and difficult history. In academic studies, a strong link between women's and girls' participation in sports and education achievement is established. Sports also play an important role in the physical, mental, emotional, social and psychological development of participants without gender discrimination. Men and women are equal definitely, however, women are still faced with the problem of gender inequality in many underdeveloped and developing countries. Gender is an important social factor that should be included in all the theoretical analyzes of sport with social class, race and age. Increasing women's visibility and participation in sports and physical activity is also important in terms of gender studies. In this context, the purpose of this study is to elucidate some of the missing issues by examining the sport in the framework of gender analysis.

\section{Giriș}

Demokratik toplumlar; sosyal adaletin, eşit hakların ve eşit firsatların her iki cinsiyet için de geçerli olması üzerine kuruludur (Edwards, 2009). Firsatlar ve yaklaşım konusundaki bu eşitlik varsayımları, karşılıklı güveni doğurur ve demokratik toplumlarda sosyal uyum ve sosyal sermayenin oluşumu için esastır. Bu nedenle eşitlik, cinsiyet eşitliği dâhil, kamu değeri olarak kabul edilir (Jorgensen ve Bozeman, 2007). Cinsiyet eşitliğine dünya çapında verilen önem, 2000 yılında Birleşmiş Milletler'in sekizinci kalkınma hedefinde de açıkça belirtilmiştir. BM'nin üzerinde durduğu bir diğer hedef ise cinsiyet eşitliğini teşvik etmenin ve kadınların güçlendirilmesinin önemidir. Cinsiyet, spor dünyasında da önemli rol oynamaktadır.

\footnotetext{
* Sorumlu yazar/Corresponding author.
}

e-posta: burak.celik@yasar.edu.tr 
Ayrıca, eşitliğin özellikle de adaletin, spor aktiviteleri ve yarışmaları için temel olduğu varsayılmaktadır. Cinsiyet, etnik köken ve cinsellik gibi sosyal güç ilişkilerine dayanan eşitsizlikler; birçok gelişmiş ülkenin anayasaları tarafından yasaklanmıştır ve aynı zamanda "haksız yaklaşım" olarak görülmektedir. Sosyal eşitsizliklerin varlığı, toplum içerisinde eşit muamele, ifade ve düşünce ideolojisinin gerçekleştirilemediğini ortaya koymaktadır. Bu eşitsizlikler, kültürlerin ve bireysel yaşamların tarihine, uygulamalarına ve deneyimlerine bağlı olarak çoğu zaman maskelenmiş veya görünmez olacak kadar derinlemesine gömülmüş karmaşık sosyal yapılardır. Bununla beraber, bu eşitsizliklerle sonuçlanan ve/veya ortaya çıkan bu uygulamalar, genellikle toplum içerisinde ortak düşünce olarak kabul edildiğinden görünmez olma eğilimindedir (Claringbould ve Knoppers, 2012; Connell, 2009). Bu durum ise var olan problemi yok etmeyi zorlaştırır. Dolayısıyla bu eşitsizlikleri üreten dinamiklerin araştırılıp görünür hale getirilmesi gerekmektedir.

Eşitlik, cinsiyet ve sporcular üzerine yapılan araştırmalar çoğu zaman kadınların spora katılımlarında ya da spor aktivitelerinde karşılaştıkları engelleri ve bu engellerin nasıl kaldırılabileceğini ya da azaltılabileceğini incelemektedir (Haveman, 2012; Sagas ve Cunningham, 2004). Örneğin, farklı spor dallarında cinsiyet eşitliği eksikliğini araştırmak için kadınların sahip ol(a)madıkları koşulların tanımlanması, buna uygun düzenlemelerin yapılması ve geliştirilmesi gerektiği vurgulanmaktadır. $\mathrm{Bu}$ şekilde eksiklikler azaltılabilir. Ayrıca kadın ve erkeklerin aynı spor dallarında aynı başarıyı gösterme şansı olduğu varsayılmaktadır. Eşitsizlik yaklaşımı, farklı spor dallarında kadınların göreceli eksikliğini açıklamak için sıklıkla kullanılmaktadır (Knoppers ve McDonald, 2010).

Kadınların spora katılımlarında yaşadıkları olumsuzluklara odaklanan bir yaklaşımın aksine, ayrımcı yaklaşım spor dallarında ayrımcı davranışları belirlemeye ve ortadan kaldırmaya odaklanmaktadır (Bogaert ve Vloeberghs, 2005; Kanter, 1977). Bu yaklaşım, spor aktivitelerine dahil olma ve/veya dışlanma engellerine ve ayrıca marjinalleşme olasıllklarına dikkat etmektedir. Kanter (1977), toplumsal cinsiyet eşitsizliklerinin sistematik olarak toplumların yapısına bağlı olduğunu vurgulayan ilk araştırmacılardan biridir. Yaşanan ayrımcılığın nasıl olduğunu ve ne şekilde önlenebileceğini inceleyerek kadınların yaşadığı ayrımcılığı tanımlamıştır. Nispeten daha az temsil edilen kadınların spor programlarına erişimde yaşadıkları olumsuzluklar ve profesyonel olarak sporda yer edinebilme firsatlarının azlığı onları spor piyasasından uzaklaştırmıştır. Sonuç olarak, kadınlar birçok spor dalından yapmayı istedikleri ya da yetenekleri olduğu halde vazgeçme eğilimindedir.

Özellikle 1970'lerde ve 1980'lerde kadınların spora katılım eksikliğini vurgulayan araştırmaların birçoğu, cinsiyet ayrımcılığını ya da yapısal yaklaşımı ya da her ikisini de çalışmalarında kullanmıştır (Knoppers ve McDonald, 2010). $\mathrm{Bu}$ yaklaşımların kullanılması, spor programları ya da aktiviteleri içerisinde cinsiyet eşitliğini artırmaya yönelik yeni politikaların belirlenmesini sağlamıştır (Ely ve Meyerson, 2000; Meyerson ve Kolb, 2000). Her ne kadar profesyonel ya da amatör anlamda spor yapan kadınların sayısı artmış olsa dahi hala istenilen düzeyde değildir. Cinsiyetin bireysel ve evrensel bir sosyal güç olduğu varsayımına dayanarak ideolojik ve güçlü bir sosyal yapı olan toplumların cinsiyet eşitliği kavramını algılayamadıklarından bu yaklaşımların yetersiz olduğunu vurgulamaktadırlar (Acker, 1990, 1992; Messner, 2009). Bu nedenle, cinsiyet eşitsizliği ile ilgili yaşanan sorunların normalleşmesi ve içselleştirilmesi; ayrıca toplumların verdiği tepkileri iyi incelemek gerekmektedir. Bu bakımdan, yapısal yaklaşımların aktif olarak uygulanabilmesi kadınların spora katılımlarını artıracağı gibi onların marjinal faydasını da artıracaktır. Bu çalışmanın amacı, ayrımcı yapılar veya bireylerin cinsiyetlerini ortaya çıkaran yaklaşımlar yerine kadınlar için spor programlarının geliştirilmesi ve yaygınlaştırılması, profesyonel hayatta homojenliğin nasıl sağlanabileceği, kadınların spora katılımının sağladığı faydayı araştırmaktır. $\mathrm{Bu}$ tür anlayışların ve politikaların uygulanması, kamu değerlerini de artıracaktır. Bu alandaki literatürün azlığı bu çalışma için sınırlayıcı bir etken olmasına rağmen ulusal ve uluslararası basılı medya, kamu ve spor federasyonlarının web siteleri bu makale için kaynak olmuştur. $\mathrm{Bu}$ çalışmanın spor kurumlarının spora katılımı artırmak için izlemesi gereken toplumsal cinsiyet eşitliği politikalarında ve ayrıca spor bilimcilerin toplumsal cinsiyet eşitliğine duyarlı çalışmalarında faydalı olacağını düşünülmektedir.

\section{Spor Yönetiminde Kadın}

Bir spor federasyonu ilgili spor dalının yurtiçindeki en üst ve tek düzenleyicisi, yöneticisi ve denetleyicisidir. Federasyon, sorumlu olduğu spor dalının faaliyetlerini düzenlemek, gelişmesini ve yaygınlaşmasını sağlamak, antrenör, hakem ve benzeri diğer spor elemanlarını yetiştirmekle yükümlüdür. Bir federasyonun başkan ve yönetim kurulunu da federasyonun genel kurulu seçer. Koca (2011) çalışmasında spor kurumlarının yönetim kademelerinde kadının temsilini araştırmak amacıyla 2010 yılı itibariyle faaliyette olan 60 spor federasyonundaki başkan ve yönetim kurullarındaki kadın sayısını incelemiştir. Bir karşılaştırma yapabilmek amacıyla aynı 60 spor federasyonundaki başkanın ve yönetim kurullarındaki erkek ve kadın sayıları bugün itibariyle tekrar incelenmiştir. Sayılar spor federasyonlarının resmi web sitelerinde yer alan başkan ve yönetim kurulu hakkındaki bilgilerden derlenmiştir. Sonuçlar Tablo 1'de gösterilmektedir. Federasyon başkanlıkları göz önüne alındığında 2010'da sadece bir federasyonun başkanı kadın iken bugün bu sayı 3'e çıkmıştır ancak hala olması gerekenden çok uzaktadır. Aradan geçen dokuz yılda yönetim kurullarındaki kadın sayısı artmasına rağmen kadınların oranı \%4.1'den \%3.91'e inmiştir.

Tablo 1.60 Spor Federasyonundaki Başkan ve Yönetim Kurullarındaki Kadın ve Erkek Sayıları (Yüzde Değerler).

\begin{tabular}{ccccc}
\hline & \multicolumn{2}{c}{$\mathbf{2 0 1 0}$} & \multicolumn{2}{c}{2019} \\
Kadın & Erkek & Kadın & Erkek \\
\hline Başkan & 1 & 59 & $3(\% 5)$ & $57(\% 95)$ \\
Yönetim & $(\% 1.6)$ & $(\% 98.4)$ & & \\
Kurulu & 28 & 650 & 34 & 835 \\
Üyesi & $(\% 4.1)$ & $(\% 95.9)$ & $(\% 3.91)$ & $(\% 96.09)$ \\
\hline
\end{tabular}

Kaynak: Koca (2011), GSGM (2019) ve yazarın kendi derlemesidir.

Türkiye'de yapılan daha detaylı araştırmalar, spor kuruluşlarında üst düzey pozisyonlardaki erkeklerin 
kadınlara oranının yüksek olduğunu göstermektedir. Örneğin, 2017 yılında ulusal spor organizasyonlarının yönetim kurullarının yüzde 17,6'sı kadındır (TMOK, 2017). Pozisyonun seviyesi arttıkça, kadın sayısı azalmaktadır. Olimpiyat Tüzüğü (Uluslararası Olimpiyat Komitesi, 2007), "bir ülke veya bir kişi ile ilgili olarak ırk, din, politika, cinsiyet veya başka bir gerekçeyle yapılan herhangi bir ayrımcılığın Olimpiyat Hareketi'nin varoluş felsefesi ile uyuşmadığını" belirtmektedir.

Spor, kadınların seslerini duyurabildikleri, klişeleri yıktıkları, toplumda var olduklarını gösterebildikleri araçlardan birisidir. Sporda firsat eşitliği eğer sporun yönetiminde de eşitlik varsa daha kolay sağlanacaktır. Tablo 1'deki karşılaştırmadan da açıkça görülüyor ki kadınların Türk toplumundaki yerinin bir yansıması olarak spor dallarındaki bu karar mercilerinde de kadının yeri yok denecek kadar azdır. Geçen dokuz yılda kadınların güçlendirilmesi için yapılan bütün çalışmalara rağmen sporun yönetimi alanında kadının yer edinebilmesi konusunda çok başarı sağlanamamıştır. Spor federasyonlarının yönetim kurullarına seçilenlerin büyük çoğunluğunun erkek olmasının en önemli nedeni seçenlerin de, yani ilgili federasyonun genel kurul üyelerinin de, büyük çoğunluğunun erkek olmasından kaynaklanmaktadır. Toplumda her alanda cinsiyet eşitsizliğini yaratan sebepler ne ise sporda bu duruma neden olan sebepler de onlardır. Ataerkil bir toplumda yer eden bu sebepler - kadınların ötekileştirilerek sosyal, ekonomik, siyasi ve toplumsal alanda dışlanması- ortadan kaldırılmadığı sürece sporda kadının sesi ara sıra duyduğumuz cılız bir haykırıştan öteye gidemeyecektir.

\section{Kadınlar İçin Spor Programlarının Geliştirilmesi}

"Kadın, spor ve gelişim” konusunu ele alan literatürde birçok makale ve kitap olması bu konuda bir ayrımcılık olduğunun göstergesidir. Neden erkeklere odaklanan ve erkeklerin spora katılımını artırmaya yönelik çalışmalar yapılmıyor? Bu soru aslında başka bir soruyu daha beraberinde getiriyor: Neden spor yapan kadınlar ve kız çocukları hala marjinal olarak kabul ediliyor? Kuşkusuz, 21. yüzyılın başlarından itibaren kız çocuklarının ve kadınların sporda aktif olarak yer alması ve spor faaliyetlerine katılması istenilen ve beklenen bir durumdur. Her ne kadar tarihsel süreçte oldukça zorluklar yaşasalar da, son 15 yılda kadınlar uluslararası spor faaliyetlerinde ilerleme kaydetmeye çalışmaktadır.

Bununla birlikte, son yıllarda her ne kadar değişim rüzgârı esiyor olsa da, kadınların spora katılımı ne yazık ki halen teoride mücadele isteyen, kültürel olarak kabul edil(e)meyen ve toplum içerisinde baskılara neden olan birçok tepki, problem ve sorunu da beraberinde getirmektedir. Üzerinde durulması gereken konular yalnızca kadınların ve kız çocuklarının spora katılımının önündeki engelleri ve fırsatları belirlemek ve bunlar için çözüm üretmek değil, aynı zamanda spora katılımın fayda ve maliyetlerinin neler olduğunu, zaman ve spor faaliyetlerindeki değişimleri ve mevcut spor girişimlerinin kadın ve kız çocukları üzerindeki etkisini de içermelidir. Ayrıca kadınların spora katılımının dikkate alınması, yalnızca kadınların spor faaliyetlerinde etkin olarak yer almasının yanında spor ile ilgili tüm çalışmaların cinsiyetçi söylemlere karşı da bizleri duyarlı hale getirmelidir.
Pek çok ülkede, kültürel ve toplumsal değerlerden dolayı kadınların erkeklere bağımlılık statüsü göz önüne alındığında, öncelikli olarak kız çocuklarına ve kadınlara odaklanılmalıdır. 1960'ların başlarında, uluslararası arenada kadın hareketinin ivme kazanmasiyla hem yasal hem de sosyal açıdan önemli başarılar elde edilmiştir. Ayrıca Birleşmiş Milletlerin kadınlara ve kadınların ekonomik kalkınmadaki yerine odaklanmasının en önemli nedeni yapısal eşitsizliklerin birçok ülkede devam etmesinden kaynaklıdır. Ekonomik Kalkınmada Kadınların rolü (WID) tüm dünyada kadınların sosyal ve ekonomik yaşamlarını iyileştirmek için kurulmuştur. Bu durum spor açısından ele alındı ̆̆ında, uluslararası spor faaliyetlerinde kadınların oranı daha ziyade Batı ülkelerinde yoğunlaşmaktadır (Hargreaves, 1999, 2000).

1970'lerin başında, özellikle kadınların katılımına odaklanmış çeşitli spor dallarına kadın sayısını artırmaya yönelik projeler geliştirilmiştir. Birleşmiş Milletler 1975 yılını kadınlar için ilk on yılın başlangıcı olarak ilan ettiğinde, bu girişimler daha da artmış; spora katılımda cinsiyet sorunları, çeşitli politikalar, programlar, projeler ve araştırma alanları ile spora entegre edilmeye başlanmıştır. $\mathrm{Bu}$ durum, erkeklerin egemen olduğu toplumsal yapılarda bir direnç oluşmasına neden olmuştur (Hargreaves, 2004).

1980'lerde sosyalist feministlerin yoksullukla mücadelede ve ataerkilliğin küresel etkilerinin erkekleri daha da güçlü hale getirdiğini anladıklarında, eşitliğin sağlanması için mevcut toplumsal cinsiyet düzeni ve sosyal hiyerarşilerin dönüşüm gerektirdiğini vurgulamaya başladılar (Hampson ve Olchawski, 2009). Bu dönüşüm içinde kadınların ve erkeklerin dâhil olduğu cinsiyete duyarlı stratejiler geliştirdiler. $\mathrm{Bu}$ değişim ile uluslararası araştırmaların, STK'ların kurulmasının ve toplum içerisinde cinsiyete duyarlı yaklaşımların gerekli olduğu, birçok ülkede kabul ald1.

Uluslararası kuruluşlar sporun toplum içerisinde yaygınlaştırılmasının toplumsal cinsiyet eşitliğini sağlamak için de uygun bir araç olduğunu kabul ettiler. Refah düzeyi yüksek Batı ülkelerinde, kız çocuklarının ve kadınların fiziksel aktiviteye katılımlarının artırılması için farkındalığın artırılmasına yönelik çalışmalar başlatıldı (Brady ve Khan, 2002; Saavedra, 2004). Bunların başında ise sporun sağlığa olan yararları gelmektedir. Spor, ayrıca belirli koşullar altında, kız çocuklarının ve kadınların kendine olan güvenlerini artırmaları ve kimliklerini geliştirmeleri için firsatlar sağlamıştır (Brady, 2005; Hargreaves, 1994; Meier, 2005; Saavedra, 2005). Tarihsel olarak, spor yalnızca erkeklerin katıldığı veya uğraştığı faaliyet olarak kabul ediliyordu (uluslararası düzeyde rekabet eden kadınlar, büyük ölçüde seçkin, üst sınıf kadınlardı). Yıllar içerisinde spora olan katılım, daha geniş bir sosyo-ekonomik sınıfa yayılmasına rağmen, erkeklerin hala spor faaliyetlerinde futbol, basketbol, kürek çekme, sörf yapmak gibi- hakim olduğu görülmektedir. Sınıf, ırk, din ve cinsel yönelim ne olursa olsun tüm kadınların spor yapma firsatları ve/veya spora katılımlarını sağlamak uluslararası alanda devam eden bir mücadeledir (Hargreaves, 1990; Messner, 1991, 2002; Theberge, 1985).

Öte yandan, kadınların sporda istedikleri gibi yer alamamaları ve ikincil konumda olmasının nedenini anlayabilmek için toplumsal cinsiyet eşitliğine dayalı 
stratejilerin ve izlenen politikaların tarihsel süreçte nasıl değiştiğini incelemek gerekmektedir (McKinnon, 1987). Birçok toplum, kadını beden, duygu ve ev ile ilişkilendirmeye eğilimli iken; erkeği akıl, mantık ve kültür ile ilişkilendirir ve kadınların bedenlerine hapsedilmesi onların kabullendikleri durumdan ayrilmamalarından kaynaklanmaktadır. Young'a (1979) göre kadınların veya kadın bedeninin ağır ve zor sportif etkinliklere dayanamayacak kadar zayıf olduğu düşünülmekte ve bu bakımdan bazı spor alanları - futbol, yelken yapmak, kürek çekmek gibi- kadınlara uygun bulunmamaktadır. Bundan dolayı, kadının sporda ikinci kişi olmasının nedeni, kadınların biyolojik açıdan farklılığı gösterilmektedir. Kadının bedeni üzerine kurulan bu hakimiyet kadınların sadece eğlence amaçlı spor yapmalarına imkan tanımıştır. Koca ve Bulgu'ya (2005) göre Rönesans - aydınlanma çağ1insanlara bilgiyi, pozitif ve aydınca düşünmeyi, sanatta yenilikleri sunarken aydınlanmanın bu etkileri kadınlara ulaşamamış; spor alanında kadınların sadece cinsiyetlerine özgü hareketler - jimnastik, yürüyüş, bisiklete binmeyapabilecekleri belirtilmiştir.

Spor etkinliklerinin değerlendirilmesi ve hatta spor kurumunun toplum içerisinde nasıl algılandığı ve tanımlandığ 1 da spor aktivitelerine cinsiyetler arasındaki katılım farklılığını ölçmek açısından önemlidir. Willis'e (1992) göre spor; ekonomi, politika, siyaset gibi alanlara kıyasla daha somut olduğundan ve gönüllü olarak katılma esasına dayandığından, yapılan spor faaliyetlerde erkek üstünlüğünün daha yaygın olduğu önemli bir toplumsal alandır. Ayrıca kişilerin spor performanslarında en önemli belirleyici fiziksel kapasitedir. Toplumsal cinsiyet eşitliği incelendiğinde, kadın ve erkek arasındaki biyolojik farklılıkların toplum içerisinde ayrıştığı ve erkeklerin üstünlüğe dönüştüğü ve bunun sonucu olarak kadınların spor faaliyetlerine katılımı fikrinin toplum içerisinde dikkate alınmamasına neden olduğu gözlemlenmektedir.

Son yıllarda, kadınlar için yeni firsatlar yaratılması ve yasal düzenlemelerin uygulanması, feminist hareketin yükselişi ve sağlık problemlerinde yaşanan artış - obezite'ye bağlı şeker, tansiyon ve kalp krizi vb.- kadınların aktif olarak spor faaliyetlerine katılımını artırmıştır. Fakat bu artış, toplum ve kültür düzeylerinde farklılık göstermekle beraber, katılımın arttığı durumlarda da artıșın sürekli ve sürdürülebilir olduğunu söylemek imkânsızdır. Mesela Türkiye'de kadınların ve genç kızların önceki yıllara kıyasla spora katılımlarında artış gözlenirken, spor yapmayı bırakan da birçok kadın vardır. Fasting ve Pfister (1997), Türkiye'de kadınların spora katılım sağlarken karşılaştıkları zorlukları araştırmış ve kadın sporcularla birebir görüşme sağlamışlardır. Araştırma sonunda kız çocuklarının ve kadınların çok küçük yaşlarda evlendirilmeleri, kadınların ev işleri ve çocuk başta olmak üzere bakım hizmetlerini üstlenmiş olması ve spor faaliyetlerinde aktif rol alan kadınların, baba ve kocanın hayatlarındaki kontrollerinin artması sonucu spor yapmaktan vazgeçen veya vazgeçtirilen kadın sayısı, neden diğer ülkelerin gerisinde olduğumuza bir cevaptır.

Bununla birlikte bazı ülkelerde ne yazık ki bazı spor faaliyetlerine kadınların katılamaması (basketbol, futbol, tenis, yüzme gibi), toplumsal cinsiyet eşitliği için uğraşırken aynı zamanda kadınları dışlamaktadır. $\mathrm{Bu}$ duruma Türkiye'den örnek vermek gerekirse, kadınlar futbol liginin ve futbol takımlarının kapatılmasıdır. Kadınlar Futbol Ligi, federasyonun yeterli bütçe ayırmaması, sponsorsuzluk alamaması ve taraftarların gösterdiği ilgisizlik yüzünden önce birçok takımın ligden çekilmesine ve sonrasında da ligin kapatılmasına neden olmuştur. Fakat durum her zaman bu şekilde olmayabilir. Koca ve Bulgu (2005) çalışmalarında belirttiği gibi, örneğin Norveç, Avrupa, Amerika ve Çin gibi ülkelerde kadın futbolu çok fazla taraftara ve sporcuya sahip olsa da, futbolun en üst düzeyinde yer alan kişilerin dahi kalıplaşmış bazı düşüncelerin dışına çıkamadığını söylemek mümkündür. Mesela, kadınların vücutlarına yapışan formalar ve kısa şortlar giymeleri, kısaca cinsel kimliklerini öne çıkarmaları, FIFA başkanı Joseph Blatter'in kadın futbolunu geliştirmek için uygulamayı düşündüğü hedefleri arasindayd1.

Türkiye'deki lisanslı sporcu sayısının cinsiyet oranı, spor faaliyetlerinde toplumsal cinsiyet eşitliğinin düzeyini ortaya koymak açısından oldukça önemli bir göstergedir. Aşağıdaki şekillerde Türkiye'de toplumsal cinsiyet eşitliği haritalaması spor faaliyetine aktif olarak katılan kadın ve erkek sporcu cinsiyet dağılımları baz alarak gösterilmektedir.

Şekil 1. Kadın ve Erkek Sporcu Sayılarının Yıllara Göre Dağılımı (Futbol Hariç)

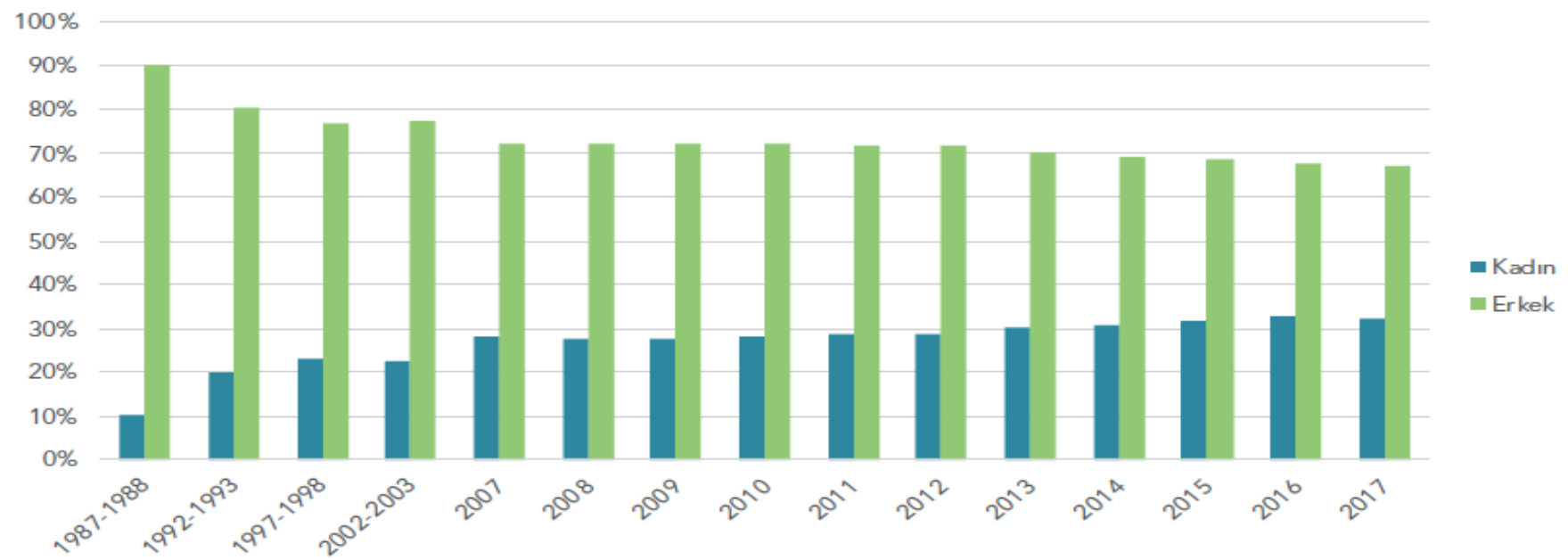

Kaynak: Koca (2018). 
Şekil 1'de görüldüğü gibi 1987-1988 yılları arasında \%9,92 olan kadın sporcu sayısı oranı (futbol hariç) zaman içerisinde artarak, 2017 yılında yaklaşı \%33 oranına yükselmiştir.

Şekil 2. Kadın ve Erkek Sporcu Sayılarının Yıllara Göre Dağılımı (Futbol Dahil)

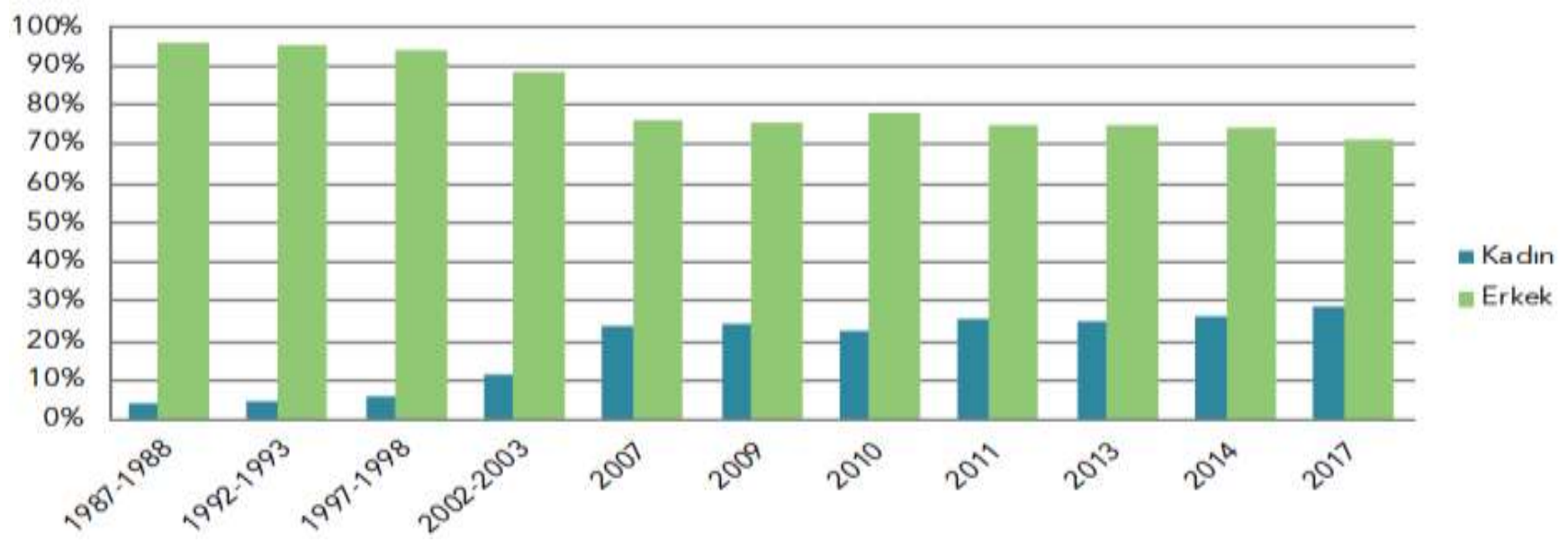

Kaynak: Koca (2018).

Futbol, spor dallarına dahil edildiğinde, kadın sporcular dezavantajlı duruma düşmektedir. Şekil 2'de görüldüğü üzere, 1987-1988 y1lları arasında \%4 oranında olan kadın sporcuların oranının 2017 yılında yaklaşık \%28 olduğu görülmektedir. $\mathrm{Bu}$ farklılığın en önemli nedeni futbola katılım sağlayan erkek sporcu oranlarının kadınlardan her yıl daha fazla olmasidır

Şekil 3. Olimpiyat Oyunlarına Katılan Sporcuların Yıllara Göre Cinsiyet Dağılımı

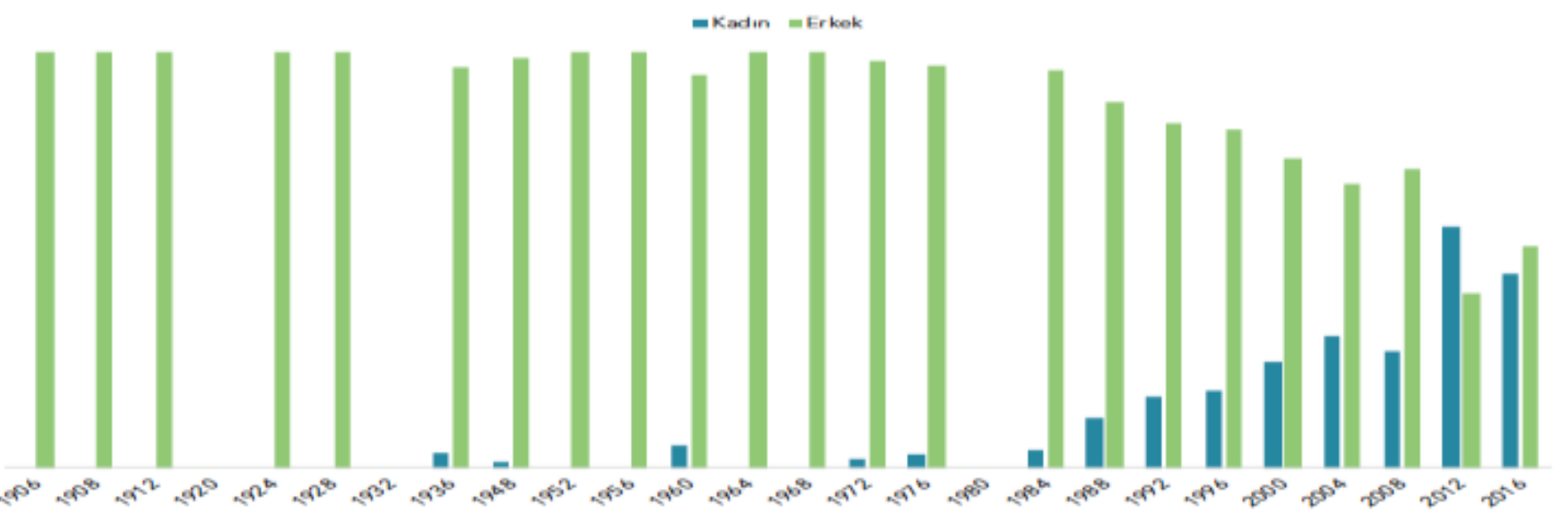

Kaynak: Koca (2018).

Türkiye, olimpiyat oyunlarına 1906 'dan itibaren (1920 ve 1982 Olimpiyatları hariç) katılım sağlamaktadır. Şekil 3'te görüldüğü gibi, 1936 yılına kadar Türkiye olimpiyatlara kadın sporcu ile katılmamışır. 1984'ten itibaren olimpiyatlara katılan kadın sporcu sayılarında artış gözlemlenmektedir. Özellikle 2012 Olimpiyatları \%58'i kadın, \%42'si erkek olmak üzere toplam 112 sporcunun katıldığı, Türk kadın sporcuların tarihte en fazla katılım gösterdiği Olimpiyat oyunları olmuştur. Basketbol ve Voleybol Kadın Milli takımlarının olimpiyat elemelerinden başarıyla geçmeleri katılımın artmasını sağlamıştır.

Şekil 4'e göre ise kadın sporcuların daha aktif oldukları spor dalları sirasıyla buz pateni (kadın \%71-erkek \%29), voleybol (kadın \%70-erkek \%30), jimnastik (kadın \%68-erkek \%32), halk oyunları (kadın \%58-erkek \%42) ve biniciliktir (kadın $\% 58-$ erkek \%42). Lisanslı sporcu sayıları ile doğru orantılı olarak kadınların en az aktif oldukları spor dalları ise sırasıyla otomobil sporları, güreş $(\% 6)$, bilardo $(\% 5)$ ve motosiklettir (\%4).
Bazı ülkelerde spora katılımda cinsiyet eşitliği kampanyaları yapıldı ve hatta bununla ilgili bildiriler hazırlandı. 1974'te Amerika'da kız çocuklarının ve kadınların spora katılımını teşvik etmek için ulusal bir kuruluş kuruldu (Kadın Spor Vakfi), 1981'de kurulan Kanadalı Kadınların Spor ve Fiziksel Aktivitede Gelişimi Derneği kadınların spora katılımını artırmaya yardımcı oldu. 1990'lı yıllarda aynı amaçla birçok uluslararası örgüt kuruldu. 1994'te Brighton, İngiltere'de düzenlenen I. Dünya Kadınlar ve Spor Konferansı'nda kadınların spora katılımını artırmak için uluslararası örgütlerin artırılmasına yönelik kararlar alındı (Meier, 2005).

Bunun gibi birçok olumlu yaklaşım, sporda cinsiyet eşitsizliğinin önündeki engelleri, eşitsizliğin ne olduğunun anlaşılması ya da bu koşullara neden olan faktörlerin araştırılmasına olanak sağlar. Toplum içerisinde cinsiyet eşitsizliklerinin ortadan kaldırılması ve kadının kendisine yüklenen kadın kimliğinden ve biyolojik farklılıktan kurtulup erkek alanlarında var olmasıyla mümkündür. Koca ve Bulgu'ya (2005) göre sporun kendi içerisinde de olan 
cinsiyet eşitsizliğinin katılım (okul takımları, spor merkezleri), yarışma (yerel, ulusal, uluslararası), liderlik (antrenör, yönetici, koç) veya medya sunumu (haber, sosyal medya, içerik analizleri) gibi kültürel ve tarihsel olarak ortaya çıartılması, sporun her bir branşında yaşanan sorunun boyutunu daha net gösterecektir.

Şekil 4. 2017 yılı federasyonlara bağlı faal lisanslı sporcuların cinsiyet dağılımı

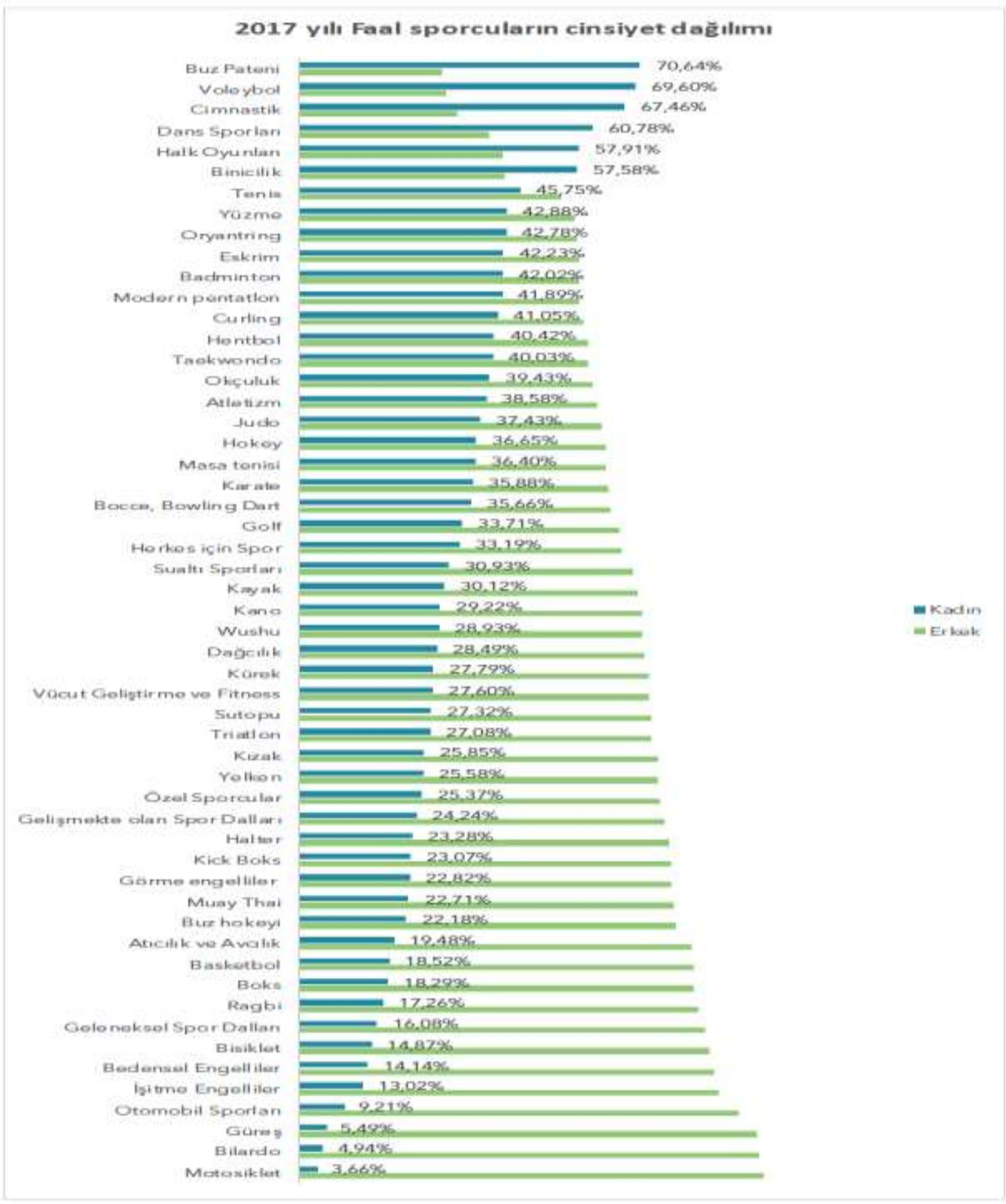

Kaynak: Koca (2018).

\section{Kadınların Spora Katılımının Yararları, Maliyetleri Ve Firsatları}

Spor faaliyetlerinin geliştirilmesinde rol oynayan faktörler ve bağlantılar özellikle de kadınların spora katılımı dikkate alındığında hala başlangıç aşamasındadır. Yine de spora olan ilgi ve geliştirilmesi için uygulanan programların ve projelerin ilerleme kaydettiği görülmektedir. Kız çocuklarının ve kadınların spor ve beden eğitimi programlarına katılımını sağlamak için sporun kız çocuklarına ve kadınlara bilinen faydalarını iyice anlatmak gerekir. Genellikle sporun fiziksel olarak sağladığı yararlar, toplum içerisinde bilinmektedir ancak hem bireyler hem de gruplar için sosyal ve psikolojik yararları da vardır. Spora katılımın disiplin, öz kontrol, öz güven, bağımsızlık, liderlik becerileri ve ayrıca kurallar çerçevesinde çalışmanın değerini öğrettiği bilinmektedir. Bunun yanında bireyler spor hedeflerine ulaşmak için fiziksel ve psikolojik etkinliklerini artırabilirler. Sosyal olarak, sporda aktif olarak katılım sağlayanlar takım çalışması, kazanma, kaybetme ve planlama konularında deneyim kazanırlar. Sosyal çevreleri genişler. Topluluklar ve hatta dünya hakkında daha fazla bilgi birikimine sahip olurlar ve bu nedenle kendilerini hayal bile edemeyecekleri pozisyonlarda bulabilirler. $\mathrm{Bu}$ tür sonuçlar, kadınların spora katılımları açısından oldukça cezbedicidir. Spora katılım, genç kadınların doğurganlıklarını kontrol etmelerini de sağlamaktadır. 
Kız çocukları ve kadınlar spor faaliyetlerine katılım sağlarken çeşitli durumlardan yararlanmaktadır. Araştırmacılar, okullar arası spor müsabakalarına katılan, lisede okuyan kız çocuklarının daha iyi notlar alabileceklerini ve istenmeyen gebeliklere sahip olma ihtimallerinin daha düşük olacağını belirtmişlerdir. Ayrıca aktif olarak spor hayatına devam eden kadın sporcuların tam zamanlı olarak çalışma olasılıklarının daha yüksek olduğu belirlenmiştir. Kadın sporcuların erkeklere kıyasla çalışma disiplini ve kurallara uyumu ile daha iyi performans gösterdiği gözlemlenmiştir (Knoppers, 2011).

Sporun dünyanın çoğunda erkeklere özgü bir aktivite olma eğilimi nedeniyle kadınları ve kız çocuklarını spora dâhil etmek için çabalayanların belirli engelleri aşmaları ve sorunlarla yüzleşmeleri gerekir. Bu durumu üç kategoride incelemek mümkündür (Hoeber, 2007):

- Güvenlik

- Zorunluluklar ve zaman kisitları

- Cinsiyet ve cinsellik normları

- Spor yapmanın maliyeti

Güvenlik çok önemlidir ve çok farklı durumda ortaya çıkabilir. Herhangi bir spor etkinliğinde katılımcılar donanım, tesis, eğitim eksikliği ve/veya diğer katılımcıların aşırı fiziksel şiddetine/risklerine maruz kalmamalıdır. Spora katılım sağlayanlar, antrenörler, eğitmenler veya kulüp temsilcileri fazla veya az eğitimden kaynaklanan kalıcı yaralanmalar ve yeme bozukluklarının yol açabileceği olumsuz sonuçları bilmeli ve bunlardan kaçınmaya çalışmalıdır. Kadınlar için fiziksel ve sosyal şiddete maruz kalmak büyük bir güvenlik sorunudur ve spora katılımlarında olumsuz etki yaratır. Sadece spor etkinliklerine katılmak bile kadınları şiddet riskine maruz bırakabilir. Bu nedenle, uygun fiyatlı ve güvenilir ulaşım, etkinlikler için makul saatler ve güvenli spor salonları kadın katılımcılar için oldukça büyük önem kazanmaktadır (Hoeber, 2008). Spor faaliyetleri genellikle kamusal alandaailenin veya toplumun olası korumasının dişındagerçekleşir. Ayrıca, boks veya futbol gibi belirli spor faaliyetleri genellikle toplum içerisinde erkeklere özgü sporlar olarak kabul edilir. Bu spor faaliyetlerinde aktif olarak yer alan ve cinsiyet sınırlarını aşan bir kadın veya kız çocuğu, ailenin veya toplumun fiziksel ve sosyal şiddetine maruz kalabilir. Sabo vd.'e (1998) göre bu açıdan aileleri, ebeveynleri ve toplumu kız çocuklarının ve kadınların spora katılımını teşvik etmeye ve hatta onları daha somut yollarla (örneğin eğitim, lojistik vb.) spor faaliyetlerine dâhil etmeye ikna etmek oldukça önemlidir.

Kadınların spor faaliyetlerine katılımını sağlamak için bir tek güvenliği sağlamak yeterli değildir. Diğer zorunluluklar ve zaman kısıtlamaları, kadınların spora katılımının artmasının önündeki en büyük engellerdir. Ekonomik koşullar ve ev içi işbölümü, kadın ve kız çocuklarının boş zamanlarının çoğunu zaten doldurmaktadır. Birçok kadın için spora katılım sağlayamamak; özellikle gıda, barınma, güvenlik, sağlık ve eğitim gibi temel ihtiyaçların yetersiz olduğu durumlarda birincil bir problem olmayacaktır. Ayrıca spor olanakları sıklıkla eğitim ile ilişkilendirilirken sınırlı kaynaklar bireysel ve kurumsal düzeyde katılım faaliyetlerini olumsuz etkileyebilir. Lyon ve Woodward'a (2004) göre spor aktiviteleri için hem alan hem de zaman yaratmak amacıyla yaratıcı ve alternatif çözümler gereklidir. Örneğin, spor faaliyetlerini müzik ve okuryazarlık programları, pazar günleri vb. gibi diğer etkinliklerle ilişkilendirmek yardımcı olabilir. Çocuk bakımı sağlama hizmetleri de büyük ölçüde katılımı artırabilir. Kuşkusuz, katılımcılar - mevcut ve gelecekteki - zaman ve kaynak kısıtlamalarını ve olası çözümleri kendileri de belirleyeceklerdir.

Son olarak, zorunluluklar ve zaman kısıtlamaları konusu, bir ölçüde kadınların, kız çocuklarının ve toplulukların önceliklerini ve beklentilerini yansıtmaktadır. Rol modelleri ve bununla ilgili olumlu sonuçlar olduğunda, kadınlar ve kız çocukları için spora katılım artacaktır. Kadınların spora katılımı ücretlendirme, eğitim bursları, seyahat firsatları ya da kaynaklara erişim gibi olanaklara imkân sağlarsa, kadınlar daha fazla cesaretlenecek ve sporu benimseyecektir.

Kadınların spora katılımlarını desteklerken dikkat edilmesi gereken bir diğer husus da cinsiyet ve cinsellik normlarında yaşanan farklılıklardır. Geliştirdiğiniz veya desteklediğiniz nasıl bir program ya da spor olursa olsun, cinsiyet ve cinsellik normları sosyo-kültürel sistemin içerisinde yer alacaktır. Kadınlar bu sistemin kendisiyle ne kadar ve/veya hangi şekilde yüzleşmek ister? Örneğin, kadınların boks programına katılımını önermek radikal olarak kabul edilebilir. 10 yaş altı çocuklar için cinsiyet gözetmeksizin futbol oynamalarını önermek daha radikal bir düşünce olabilir. Tamamen kadınlardan oluşan voleybol, spora ilişkin bazı cinsiyetçi normlara uyabilir ancak bu durumda kız çocuklarının diğer alanlarda etkin olmasını engelleyebilir (Claringbould ve Knoppers, 2012).

Sporda 'cinsiyet eşitliği', profesyonel olarak sporla ilgilenen kadınlara ayrım yapmadan ekonomik ve sosyal anlamda aynı koşullarda davranılması anlamına gelir. Ne yazık ki, spor faaliyetlerine katılım ve sporda lider olmak hâlâ erkek hegemonyasındadır. Spor dünyasında erkekler ve kadınlar arasında artan bu eşitsizliği ele almak giderek daha önemli hale gelmektedir. Herhangi bir spor faaliyetine katılan kadın sayısının artması, toplumsal cinsiyet eşitsizliğini azaltmak ve kadınların spor girişimlerine destek vermek açısından oldukça önemlidir.

\section{Sonuç}

Sporun toplumsal etkisini uluslararası kalkınma bağlamında araştırmak, araştırmacıların kullandıkları yaklaşımların teknik uyarlamalarından daha fazlasını gerektirir. Spor sistemlerinin yapısını baz alan bir araştırma modeli kültürel olarak topluma ya da ülkeye özeldir. Giriş bölümünde belirtildiği gibi, cinsiyet kavramı, içeriğe bağlı olarak değişen ve yeniden inşa etme kapasitesine sahip bir sosyal yapıdır. Spora ilişkin olarak, katılımı etkileyen birçok cinsiyet rolü beklentileri bulunmaktadır. Kadınların spora erişimi, genellikle ev içi sorumluluk, çocuk bakımı ve taleplerinin bir sonucu olarak kısitlanmaktadır. Her ne kadar spor, belirli koşullar altında, kadınlara yeni ve özgürleştirici kimlikleri geliştirmek ve cinsiyet tanımının sınırlarını zorlamak için bir imkân sağlasa da spor programları, faaliyetleri ve aktiviteleri oluşturulurken cinsiyetlere odaklanmaya devam edilmelidir. Ayrıca eşitlik ve eşitçilik arasındaki farkı göz önünde bulundurmak önemlidir. Uluslararası Sporda Çalışan Kadın Çalışma Grubu (2002), "Cinsiyet eşitliği, kadınlar ve erkekler için kaynakların ve fursatların adil ve eşit şekilde tahsis edilmesinin ilke ve uygulamasıdır. Cinsiyet eşitliği, her iki cinsiyetten birinin 
tam katılımına engel olan ayrımcı uygulamaları ortadan kaldırır." diye belirtir. Eşitlikçi uygulama, farklı grupların aynı koşullara erişimini sağlamak için farklı muamelelerin kullanılmasını içerir. Buna karşılık eşitlik, farklı grupların farklı ihtiyaçları ve "başlangıç noktaları" dikkate almadan benzer davranışı ve sonuçları uygulamaktır. Çünkü her spor faaliyeti, eşit fursat ve eşit sonuç ile ilişkilendirilemez. Bu açıdan, spora katılım ve cinsiyet programlarının adil uygulanması kız çocuklarının ve kadınların spora katılımlarında pozitif etki yaratacaktır.

Bu çalışmanın amacı da, tek bir çözümü tanımlamak değil, kız çocukları ve kadınlar için mevcut spor olanaklarıyla ilgili yaşadıkları sorunları tanımlamaktır. Kız çocuklarının ve kadınların spora katılımlarının doğasında var olan sorunların çözümleri ne olursa olsun, net olan bir şey vardır: K1z çocuklarına ve kadınlara sunulan spor aktivitelerine katılıma yönelik mevcut modelin alternatifsiz bir erkek modeli olmasıdır. Bununla beraber, kız çocuklarının ve kadınların spora katılmak istememesi ya da yetersiz olma varsayımları bu modele dayandırılmaktadır.

Cinsiyet eşitliğinin ve kız çocukları ile kadınların spora katılımının artırılması için yapılan çalışmalar son yıllarda artış göstermektedir. Ulusal veya uluslararası kurumlar, özellikle kadınların ve kız çocuklarının sporun tüm alanlarına katılımlarındaki dengesizliğini ortadan kaldırmak için birçok politika üretmiş ve uygulamaya başlamıştır. Bununla birlikte, cinsiyetçi yaklaşımı ortadan kaldırmak için kadınların karar verme ve liderlik pozisyonlarında yer almalarını sağlamak, sporda şiddet, istismar ve tacize karşı savaşmak için politikalar geliştirmeye ve uygulamaya başlamışlardır. Ayrıca, kız çocuklarının ve kadınların sporun tüm dallarında aldıkları başarıların Uluslararası Olimpiyat Komitesi tarafından 2000 yılından itibaren 'Kadın ve Spor Ödülü’ ile ödüllendirilmeye başlanmış olması spora olan katılımı daha da artırmıştır.

\section{Kaynakça}

Acker, J. (1990). Hierarchies, Jobs, Bodies: A Theory of Gendered Organizations. Gender and Society, 4, 139158.

Acker, J. (1992). Gendering Organizational Theory. Gendering Organizational Analysis, Haz. Albert J. Mills ve Peta Tancred. Newbury Park, US: Sage Publications.

Bogaert, S. \& Vloeberghs, D. (2005). Differentiated and Individualized Personnel Management. European Management Journal, 23, 483-493.

Brady, M. \& Arjmand, B. K. (2002). Letting Girls Play: The Mathare Youth Sport Association's Football Program for Girls. Population Council. Erişim: https://www.popcouncil.org/uploads/pdfs/girlsplay.pdf

Brady, M. (2005). Creating Safe Spaces and Building Social Assets for Young Women in the Developing World: A New Role for Sports. Women's Studies Quarterly, 33(1\&2), 35-49.

Claringbould, I. \& Knoppers, A. (2007). Finding a "Normal" Woman: Selection Processes for Board Membership. Sex Roles, 56, 495-507.
Claringbould, I. \& Knoppers, A. (2012). Paradoxical Practices of Gender in Sport Related Organizations. Journal of Sport Management, 26(5), 404-16.

Connell, R. (2009). Gender in World Perspective. Cambridge: Polity Press.

Edwards, S. D. (2009). Three Versions of an Ethics of Care. Nursing Philosophy, 10, 231-240.

Ely, R. J. \& Meyerson, D. E. (2000). Advancing Gender Equity in Organizations: The Challenge and Importance of Maintaining a Gender Narrative. Organization, 7, 589-608.

Fasting, K. \& Pfister, G. (1997). Opportunities and Barriers for Sport for Women in Turkey: A Pilot Study. Yayımlanmamış çalışma, Berlin/Oslo.

Hampson, T. \& Olchawski, J. (2009). Is equality fair? London: Fabian Society.

Hargreaves, J. (1990). Gender on the Sports Agenda. The International Review for the Sociology of Sport, 25(4), 287-307.

Hargreaves, J. (1994). Sporting Females, Critical Issues in the History and Sociology of Women's Sports. London and New York: Routledge.

Hargreaves, J. (1999). The 'Women's International Sports Movement': Local-Global Strategies and Empowerment. Women's Studies International Forum, 22(5), 461-471.

Hargreaves, J. (2000). Heroines of Sport: The Politics of Difference and Identity. London: Routledge.

Hargreaves, J. (2004). Querying Sport Feminism: Personal or Political. Sport and Modern Social Theorists. Haz. Richard Giulianotti. Basingstoke: Plagrave.

Haveman, H. (2012). If You're So Smart, Why Aren't You the Boss? Explaining the Persistent Vertical Gender Gap in Management. Annals of the American Academy of Political and Social Science, 639, 114-130.

Hoeber, L. (2007). Exploring the Gaps between Meanings and Practices of Gender Equity in a Sport Organization. Gender, Work and Organization, 14, 259-280.

Hoeber, L. (2008). Gender Equity for Athletes: Multiple Understandings of an Organizational Value. Sex Roles, 58, 58-71.

Jorgensen, B. T. \& Bozeman, B. (2007). Public Values: An Inventory. Administration and Society, 39(3), 354-381.

International Working Group on Women and Sport (2002). The Montreal Tool Kit. Montreal, Canada, Erişim: http://www.canada2002.org/pdf/toolkit_eng.pdf

Kanter, R. M. (1977). Men and Women of the Corporation. New York: Basic Books.

Knoppers, A. \& McDonald, M. (2010). Scholarship on Gender and Sport in Sex Roles and Beyond. Sex Roles, 63, 311-323.

Knoppers, A. (2011). Giving Meaning to Sport Involvement in Managerial Work. Gender, Work and Organization, 18, 1-22. 
Koca, C. (2011). Spor Kurumlarının Yönetim Kademelerinde Kadınların Temsili. Hacettepe Spor Bilimleri Dergisi, 22(1), 1-12.

Koca, C. (2018). Toplumsal Cinsiyet Eşitliğinin İzlenmesi Projesi: Sporda Toplumsal Cinsiyet Eşitliği Haritalama ve İzleme Çalışması. Ankara: CEID Yayınları:11, Nika Yayınları.

Koca, C. \& Bulgu N. (2005). Spor ve Toplumsal Cinsiyet: Genel Bir Bakış. Toplum ve Bilim, 103, 163-184.

Lyon, D. \& Woodward, A. (2004). Gender and Time at the Top: Cultural Constructions of Time in High-Level Careers and Homes. European Journal of Women's Studies, 11, 205-221.

McKinnon, C. (1987). Feminism Unmodified: Discourses on Life and Law. Cambridge: Harvard University Press.

Meier, M. (2005). Gender Equity, Sport and Development. Swiss Academy for Development Working Paper: Biel. Erişim:

http://citeseerx.ist.psu.edu/viewdoc/download?doi=10.1.1.4 $67.364 \&$ rep $=$ rep $1 \&$ type $=$ pdf

Messner, M. (1991). Power at Play: Sports and the Problem of Masculinity. Boston: Beacon Press.

Messner, M. (2002). Taking the Field: Women, Men, and Sports. Minneapolis: University of Minnesota Press.

Messner, M. (2009). It's All for the Kids: Gender, Families, and Youth Sports. Berkeley, CA: University of California Press.

Meyerson, D. E. \& Kolb, D. M. (2000). Moving Out of the 'Armchair': Developing a Framework to Bridge the Gap Between Feminist Theory and Practice. Organization, 7, 553-571.

Saavedra, M. (2004). Gender and Sport. A Companion to Gender Studies. Haz. Philomena Essed, Audrey
Kobayashi ve D. T. Goldberg. London: Blackwell Publishing.

Saavedra, M. (2005). Sport. A Companion to Gender Studies. Haz. Philomena Essed, David Theo Goldberg ve Audrey Kobayashi. Oxford: Blackwell. 437-454.

Sabo, D., Miller, K., Farrell, M., Barnes, G. \& Melnick, M. (1998). The Women's Sports Foundation Report: Sport and Teen Pregnancy. New York: Women's Sports Foundation.

Sagas, M. \& Cunningham, G. (2004). Does Having the 'Right Stuff' matter? Gender Differences in the Determinants of Career Success Among Intercollegiate Athletic Administrators. Sex Roles, 50, 411-421.

Theberge, N. (1985). Toward a Feminist Alternative to Sport as a Male Preserve. Quest, 37(2), 193-202.

Türkiye Milli Olimpiyat Komitesi (2017). Erişim: 18 Mart 2019, http://www.olimpiyatkomitesi.org.tr/Detay/Faaliyetleri miz/Spor-Kulturu-ve-Olimpik-Egitim-Sunumlari(Oli)/14/1

Uluslararası Olimpiyat Komitesi (2007). Erişim: 18 Mart 2019,

http://www.olimpiyatkomitesi.org.tr/Upload/Menu/8124 95tuzuk.pdf

Willis, P. (1992). Women in Sport in Ideology. Sport, Culture and Ideology. Haz. Jennifer Hargreaves. London: Routledge.

World Conference on Women and Sport (2002). The Montreal Tool Kit, Montreal, Canada, Erişim: 18 Mart 2019, http://www.canada2002.org/pdf/toolkit_eng.pdf

Young, I. (1979). The Exclusion of Women from Sport: Conceptual and Existential Dimensions. Philosophy in Context, 9, 44-53. 